\title{
Pemberdayaan Kelompok Arisan Ibu-Ibu Perumahan Lancang Kuning Melalui Pelatihan Pembuatan Nugget Jantung Pisang
}

\author{
Rini Nizar ${ }^{1}$, Latifa Siswati², Anto Ariyanto ${ }^{3}$ \\ 1,2,3Program Studi Agribisnis, Fakultas Pertanian, Universitas Lancang Kuning \\ *e-mail : rininizar@unilak.ac.id, latifasiswati@unilak.ac.id,
}

\begin{abstract}
The group of mothers domiciled in Lancang Kuning Rumbai Housing was formed as a forum for silahturahmi between citizens and to share knowledge skills that can be implemented. Arisan meetings are held once a month, routine events are activities of gathering and matching arisan, while activities that are more useful for this group are rarely carried out as already mandated by all participants at the beginning of its formation. The P2M team from the Faculty of Agriculture offers to provide training in making banana heart nuggets as one of the creativity of banana heart processing as a food that is good to consume and also good for health. This training is given because of the raw materials that are easily obtained around Lancang Kuning Housing. The external targets to be achieved from this activity are 1) improving the knowledge and skills of the Partner group 2) scientific articles. The method used to achieve the goal is by means of: 1) counseling. 2) training, and 3) evaluation. The results of the activity showed that in this devotional activity there was an increase in the knowledge and skills of participants to the benefits of consuming processed ingredients from the heart of bananas as an additional food family menu. To help the government's food diversification program, it is necessary to do activities by developing other products with banana heart raw materials and socializing other menus from banana heart.
\end{abstract}

Keywords : Nutrition, Nuggets, Banana Heart, Family Menu

\begin{abstract}
Abstrak
Kelompok arisan ibu-ibu yang berdomisili di Perumahan Lancang Kuning Rumbai dibentuk sebagai wadah silahturahmi antar warga dan membagi ilmu pengetahuan ketrampilan yang dapat diimplementasikan. Pertemuan arisan yang dilakukan setiap satu bulan sekali ini, acara rutin yang dilaksanakan adalah kegiatan pengumpulan dan pengocokan arisan, sementara kegiatan yang lebih bermanfaat bagi kelompok ini jarang dilaksanakan seperti yang sudah dimufakatkan oleh seluruh peserta pada awal pembentukkannya. Tim P2M dari Fakultas Pertanian menawarkan untuk memberikan pelatihan pembuatan nugget jantung pisang sebagai salah satu kreatifitas pengolahan jantung pisang sebagai makanan yang enak dikonsumsi dan juga baik untuk kesehatan. Pelatihan ini diberikan karena bahan baku yang mudah diperoleh disekitar Perumahan Lancang Kuning. Target luaran yang ingin dicapai dari kegiatan ini adalah 1) peningkatan pengetahuan dan ketrampilan kelompok Mitra 2) artikel ilmiah. Metode yang digunakan untuk mencapai tujuan adalah dengan cara: 1) penyuluhan. 2) pelatihan, dan 3) evaluasi. Hasil kegiatan menunjukkan bahwa didalam kegiatan pengabdian ini terjadi peningkatan terhadap pengetahuan dan keterampilan peserta terhadap manfaat mengkonsumsi bahan olahan dari jantung pisang sebagai makanan tambahan menu keluarga. Untuk membantu program diversifikasi pangan pemerintah maka perlu dilakukan kegiatan dengan mengembangkan produk lain dengan bahan baku jantung pisang dan mensosialisasikan menu lain dari jantung pisang.
\end{abstract}

Kata kunci : Gizi, Nugget, Jantung Pisang, Menu Keluarga

\section{PENDAHULUAN}

Pemberdayaan masyarakat merupakan proses pembangunan yang melibatkan masyarakat untuk berinisiatif memulai proses kegiatan sosial dengan berpartisipasi sebagai agen pembangunan. Salah satu pemberdayaan masyarakat adalah perkumpulan ibu-ibu arisan yang merupakan wadah perkumpulan non formal dalam masyarakat sebagai bentuk fenomena sosiologi yang memberikan solidaritas sosial dan pengaruh baik secara langsung maupun tidak 
langsung dirasakan oleh masyarakat, atau dengan perkataan lain kelompok arisan ibu rumah tangga adalah bagian dari kehidupan masyarakat yang dapat membantu meningkatkan rasa solidaritas sosial dan menunjang kegiatan sosial lain (Sarmalina et al., 2019).

Untuk masyarakat terutama kelas menengah dan bawah tugas seorang ibu selain menjadi ibu dan istri juga membantu ekonomi keluarga, keberadaan ibu-ibu ini merupakan salah satu potensi untuk bisa mengembangkan kegiatan produktif di lingkungan terkecil atau kelurahan dengan memanfaatkan waktu luangnya dengan kegiatan wirausaha (Prasetyo and Saddewisasi, 2014). Keberdayaan perempuan di bidang ekonomi juga merupakan salah satu indikator meningkatnya kesejahteraan. Perempuan juga mempunyai andil besar dalam kegiatan penanggulangan kemiskinan melalui pemberdayaan masyarakat dan kelompok dengan melakukan kegiatan usaha produktif rumah tangga (Susanti and Susilowati, 2016).

Kegiatan arisan ibu rumah tangga di Perumahan Lancang Kuning Kelurahan Umbansari Kecamatan Rumbai Kota Pekanbaru selain sebagai wadah pemersatu dan perekat kebersamaan antar warga, terutama ibu-ibu, disamping itu kegiatan perkumpulan ini dapat juga diselingi dengan kegiatan yang dapat menambah pengetahuan serta keterampilan seperti pelatihan pembuatan nugget jantung pisang yang bahan baku-nya mudah diperoleh disekitar perumahan. Menjaga pola makan yang sehat serta bergizi juga seimbang di era pandemi Covid-19 saat ini merupakan bagian penting dalam rangka mendukung sistem daya tahan tubuh sehingga berdampak kepada sistem imun yang kuat.

Bahan utama pembuatan nugget jantung pisang adalah jantung pisang yang merupakan cikal bakal buah pisang. Jantung pisang sering kali tidak dimanfaatkan atau dibuang padahal jantung pisang dapat diolah menjadi berbagai makanan yang lezat. Jantung pisang merupakan bagian dari pohon pisang yang terdiri dari kulit luar yang berwarna merah tua, daging berwarna putuh kekuningan yang ada di dalamanya, dan bunga pisang yang berada di bagian atas nya.

Dalam satu jantung pisang ada berbagai nutrisi, seperti kalium, vitamin A, vitamin C, vitamin E, mineral, asam lemak, asam amino esensial dan non esensial yang diperlukan tubuh (Alodokter, 2020). Berdasarkan penelitian (Hubaya, Karimah and Sulima, 2016) menyatakan bahwa jantung pisang merupakan jenis makanan yang mengandung Laktogogum yaitu suatu zat gizi yang dapat meningkatkan dan memperlancar produksi Air Susu Ibu (ASI) terutama pada ibu yang mengalami masalah dalam produksi ASI.

Jantung pisang dapat diolah menjadi berbagai menu makanan, pada umumnya jantung pisang dimasak tumis,di gulai atau dibuat menjadi berbagai menu lainnya, inovasi baru dalam pengolahan jantung pisang sebagai makanan adalah nugget jantung pisang sebagai makanan yang sehat dan bergizi. Nugget adalah suatu bentuk produk daging giling yang dibumbui, kemudian diselimuti perekat tepung (batter), pelumuran tepung roti (breading), dan kemudian digoreng setengah matang lalu dibekukan untuk mempertahankan mutunya selama penyimpanan. Hanya saja untuk nugget jantung pisang bahan dasar daging diganti dengan jantung pisang (Novitasari et al., 2013).

Permasalahan yang dihadapi oleh mitra adalah: kegiatan yang dilakukan oleh kelompok ibu-ibu arisan di perumahan Lancang Kuning hanya sebatas melakukan arisan dan juga pengajian yasin, sehingga kegiatan kelompok ini masih belum optimal diisi dengan kegiatan-kegiatan produktif. Tim pengabdian masyarakat dari Fakultas Pertanian Unilak menawarkan kepada kelompok untuk melakukan kegiatan pemberian pengetahuan serta pelatihan cara pembuatan nugget jantung pisang sebagai bahan makanan yang sehat dan bergizi yang mana bahan bakunya dapat ditemukan di sekitar rumah yaitu jantung pisang.

Solusi yang ditawarkan pada kegiatan Pengabdian Kepada Masyarakat ini adalah : 1) Meningkatkan pengetahuan mitra dengan penyuluhan, dan demonstrasi; 2) Memberikan 
demonstrasi atau pelatihan pembuatan nugget jantung pisang.

\section{METODE}

Pelaksanaan kegiatan pengabdian kepada masyarakat dilaksanakan kepada ibu-ibu arisan Perumahan Lancang Kuning, Kelurahan Umbansari, Kecamatan Rumbai, Kota Pekanbaru. Metode yang digunakan adalah Penyadaran/penyuluhan yang bertujuan untuk memberikan pengetahuan kepada mitra tentang ketahanan pangan dan manfaat konsumsi pangan dengan bahan dasar jantung pisang yang dapat diolah menjadi makanan menu keluarga. Kemudian, Demonstrasi yang bertujuan menunjukkan kepada mitra tentang cara pengolahan jantung pisang menjadi nugget sebagai tambahan menu keluarga yang sehat dan bergizi. Lalu, evaluasi yang dilakukan dengan menyebarkan kuesioner sebelum dan sesudah kegiatan dilakukan untuk mengukur peningkatan pengetahuan dan manfaat kegiatan.

Pada demonstrasi diperagakan cara mengolah nugget jantung pisang. Bahan dan caranya sebagai berikut : (1) Bahan : jantung pisang yang telah dikupas dan diambil bagian yang lembut, bawang merah, bawang putih, merica bubuk, garam secukupnya, telur, tepung terigu dan tepung panir. Cara memasak : rebua air hingga mendidih dan masukkan jantung pisang sekitar 10 menit, dinginkan jantung pisang kedalam air biasa, potong kecil-kecil daging jantung pisang untuk memudahkan proses penggilingan, pada saat penggilingan campurkan bawang merah; bawang putih; merica dan garam, bahan yang sudah digiling kemudian dilanjutkan dengan proses pengadonan menggunakan mixer, bahan campuran adonan adalah telur dan tepung terigu, setelah bahan tercampur masukkan adonan kedalam plastik atau cetakan kemudian direbus kembali selama 10 menit, dinginkan adonan untuk memudahkan pemotongan, setalah dipotongpotong sesuai dengan ukuran yang diinginkan lalu digoreng, sebelum digoreng oleskan daging hantung pisang ke telur dan oleskan ke tepung panir kemudian goreng hingga matang, nugget jantung pisang siap dihidangkan dan dikonsumsi.

Metode yang digunakan dalam melakukan kegiatan ini adalah pemberdayaan masyarakat dengan memberikan penyuluhan dan demonstrasi cara membuat nugget jantung pisang. Kandungan gizi dalam 100 gr olahan jantung pisang untuk nugget adalah Kalori 31 kal; Protein 1,2 g; Lemak 0,3 g; Karbohidrat 7,1 g; Kalsium 30 mg; Fosfor 50 mg; Zat besi 0,1 mg; Vitamin A 170 mg; Vitamin B1 0,05 mg; Vitamin C 10 mg dan Air 90,2 (Rukmana, 2001).

\section{HASIL DAN PEMBAHASAN}

Kegiatan Pengabdian Kepada Masyarakat ini dilaksanakan pada kelompok ibu-ibu arisan Perumahan Lancang Kuning, Kelurahan Umbansari, Kecamatan Rumbai, Kota Pekanbaru. Kelompok ini mempunyai anggota sebanyak 28 orang yang rutin melakukan kegiatan tiap bulannya, tetapi yang aktif datang tidak semua anggota apalagi pada masa pandemi ini. Selama ini acara rutin bulanan yang dilakukan adalah kegiatan arisan dan pengajian yasin, sudah ada rencana untuk mengisi kegiatan dengan kegiatan-kegiatan yang produktif tetapi masih belum terlaksana. Tim Pengabdian Masyarakat dari dosen Program Studi Agribisnis Universitas Lancang Kuning melibatkan mahasiswa untuk mengisi kegiatan arisan dengan memberikan penyuluhan dan demonstrasi pembuatan nugget jantung pisang.

Kegiatan ini diharapkan dapat memotivasi ibu-ibu untuk menambah menu sehat keluarga dan dapat melakukan usaha komersil untuk menambah pendapatan keluarga. Hal ini sesuai dengan program pemerintah meningkatkan atau menciptakan pengusaha-pengusaha baru yang dapat memperbaiki ekonomi mulai dari lingkungan yang kecil. Dikemukakan oleh Kementerian Koperasi \& UKM dalam (Nursiah, Kusnadi and Burhanuddin, 2017) bahwa Di Indonesia jumlah wirausahawan sebanyak 3,1\% dari jumlah populasi penduduk, masih kecil dibandingkan dengan 
Malaysia (5\%) dan Singapura (7\%).

Walaupun banyak anggota yang tidak dapat hadir pada kegiatan ini karena adanya pandemi, namun peserta yang hadir sangat memperhatikan kegiatan ini, dengan banyaknya pertanyaan yang diajukan pada saat penyuluhan maupun demo pembuatan nugget jantung pisang. Gambar-gambar kegiatan dapat dilihat berikut ini, mulai dari kegiatan penyuluhan, demonstrasi kegiatan, sampai dengan foto bersama.
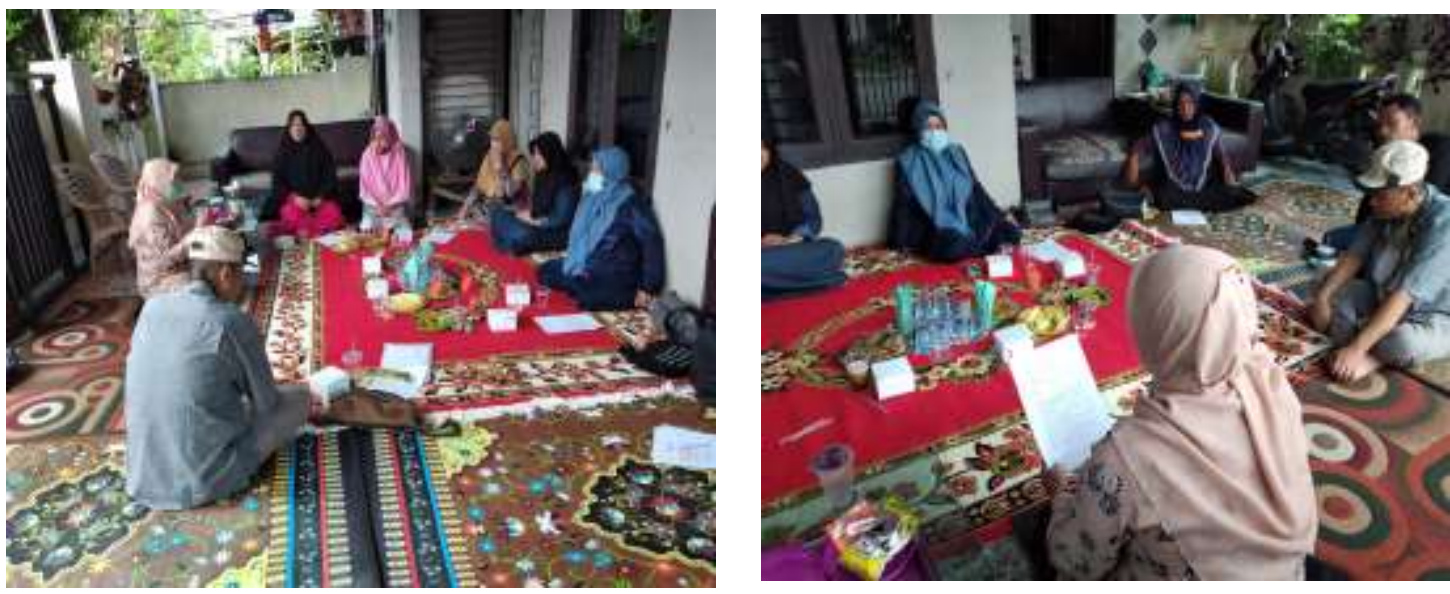

Gambar 1. Kegiatan Di Mulai Dengan Penyuluhan
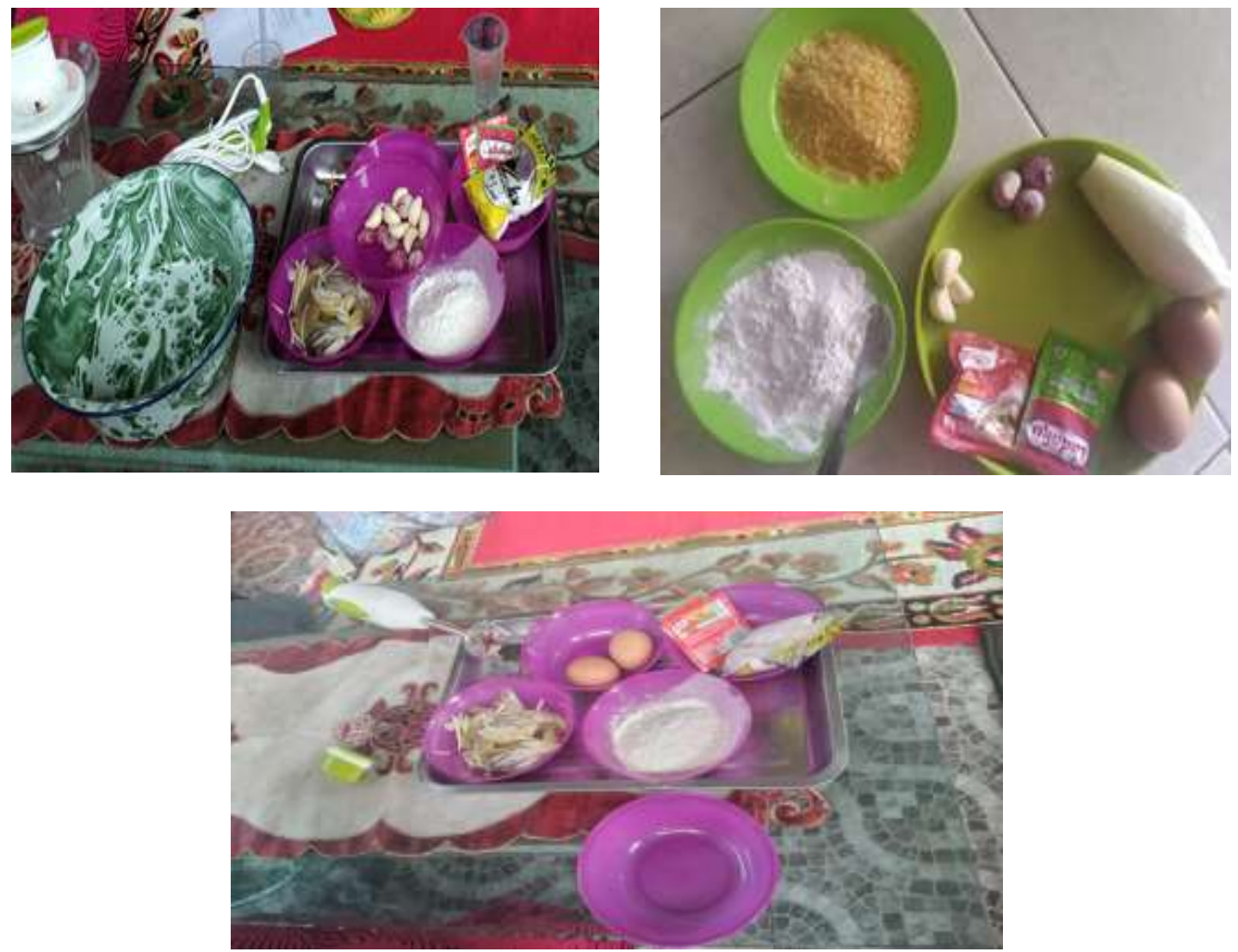

Gambar 2. Bahan Dan Alat Membuat Nugget Jantung Pisang 


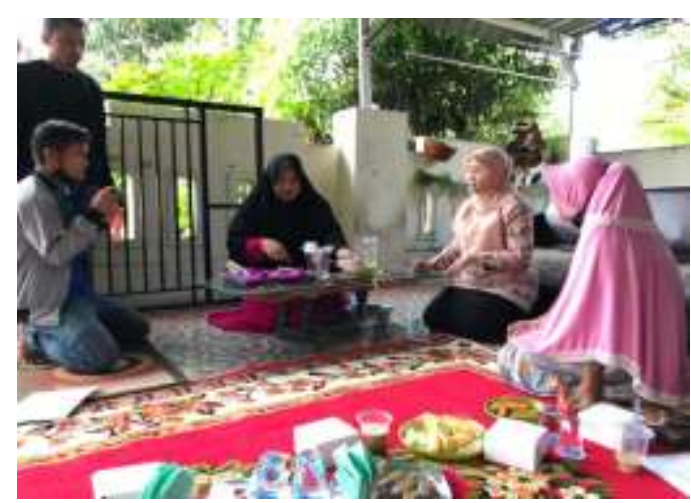

Gambar 3. Demonstrasi Pembuatan Nugget

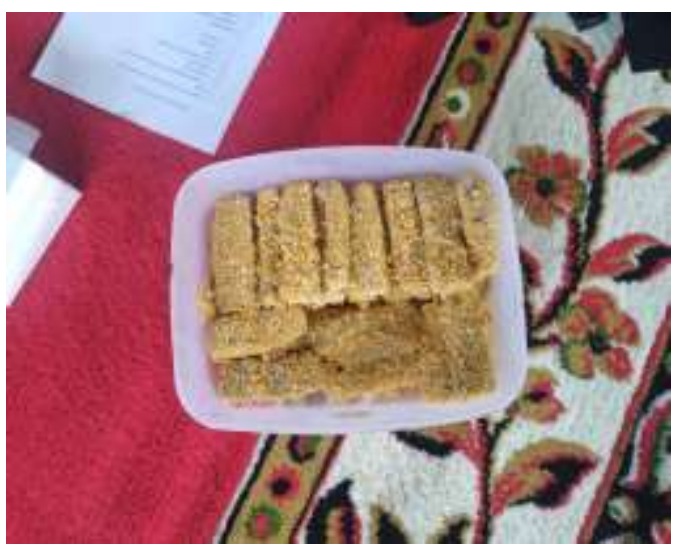

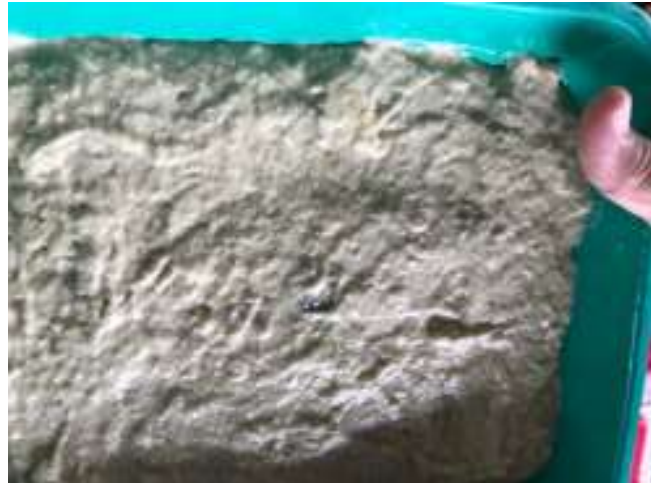

Gambar 4. Adonan Nugget Siap Kukus

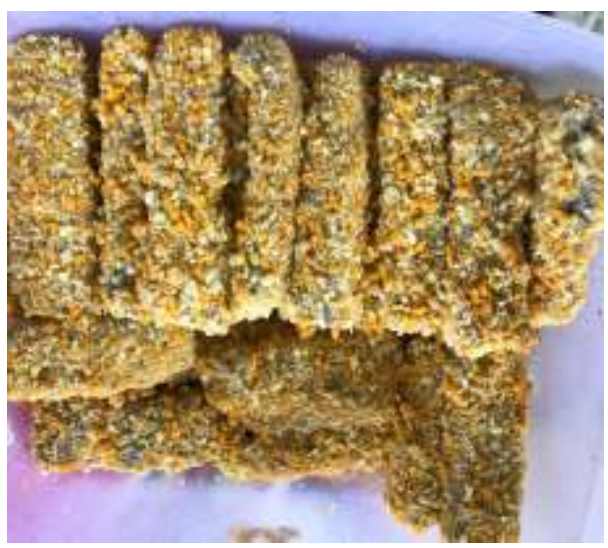

Gambar 5. Nugget Jantung Pisang Siap Makan

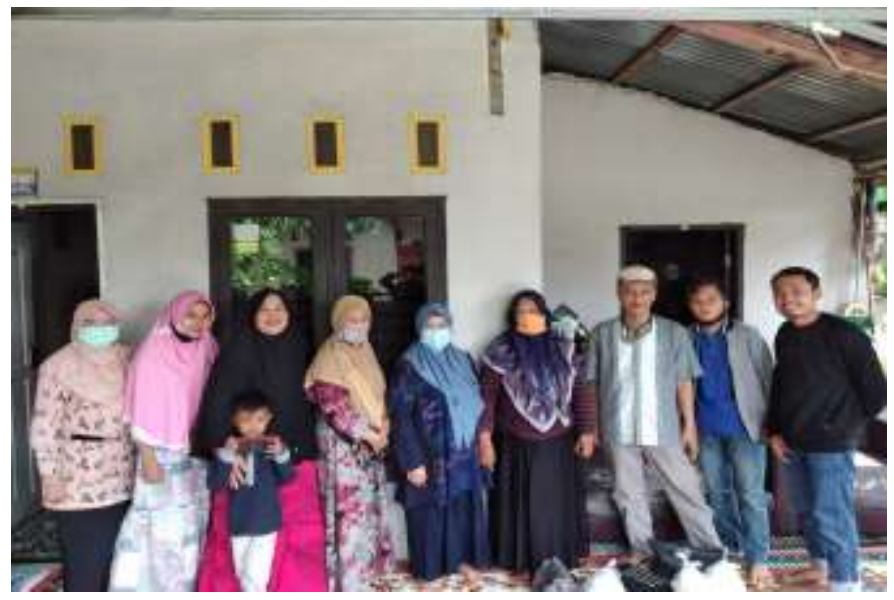

Gambar 6. Foto Bersama Sesudah Kegiatan PKM

Hasil evaluasi kuesioner sebelum dan sesudah untuk mengetahui apakah terjadi peningkatan pengetahuan dan manfaat kegiatan pada tabel 1 berikut : 
Tabel 1. Hasil Pengukuran Tingkat Pengetahuan dan Manfaat Peserta Pengabdian

\begin{tabular}{|c|c|c|c|c|}
\hline No. & Uraian & $\begin{array}{l}\text { Prosentase Jawaban } \\
\text { Peserta Sebelum (\%) }\end{array}$ & $\begin{array}{c}\text { Prosentase } \\
\text { Jawaban Peserta } \\
\text { Sesudah (\%) }\end{array}$ & $\begin{array}{c}\text { Peningkatan } \\
(\%)\end{array}$ \\
\hline 1. & $\begin{array}{l}\text { Apakah sudah pernah } \\
\text { mendapatkan } \\
\text { penyuluhan/pelatihan tentang } \\
\text { pengolahan nugget jantung } \\
\text { pisang? }\end{array}$ & 0 & 100 & 100 \\
\hline 2. & $\begin{array}{l}\text { Apakah kegiatan pengabdian } \\
\text { masyarakat yang } \\
\text { diselenggarakan ini sesuai } \\
\text { dengan harapan }\end{array}$ & 0 & 100 & 100 \\
\hline 3. & $\begin{array}{l}\text { Apakah personil/anggota yang } \\
\text { terlibat dalam kegiatan } \\
\text { pengabdian masyarakat } \\
\text { memberikan pelayanan sesuai } \\
\text { dengan kebutuhan }\end{array}$ & 10 & 100 & 90 \\
\hline 4. & $\begin{array}{l}\text { Apakah Setiap } \\
\text { keluhan/pertanyaan/permasa } \\
\text { lahan yang di ajukan } \\
\text { ditindaklanjuti dengan baik } \\
\text { oleh narasumber/anggota } \\
\text { yang terlibat }\end{array}$ & 10 & 100 & 90 \\
\hline 5. & $\begin{array}{l}\text { Apakah jika kegiatan ini } \\
\text { diselenggarakan kembali, saya } \\
\text { bersedia untuk } \\
\text { berpartisipasi/terlibat }\end{array}$ & 0 & 100 & 100 \\
\hline 6. & $\begin{array}{l}\text { Apakah ibu merasa puas } \\
\text { dengan kegiatan pengabdian } \\
\text { masyarakat yang } \\
\text { diselenggarakan tim dosen } \\
\text { agribisnis Faperta unilak }\end{array}$ & 10 & 100 & 90 \\
\hline 7. & $\begin{array}{l}\text { Apakah Kegiatan pengabdian } \\
\text { ini sangat bermanfaat }\end{array}$ & 0 & 100 & 100 \\
\hline
\end{tabular}

Tabel 1 menunjukkan terjadi peningkatan pengetahuan serta manfaat tentang pengolahan jantung pisang sebagai bahan baku nugget bagi ibu-ibu arisan di Perumahan Lancang Kuning Kelurahan Umbansari Kecamatan Rumbai Kota Pekanbaru. Pada awalnya, ibu-ibu arisan perumahan Lancang Kuning belum pernah mendapatkan penyuluhan/pelatihan tentang pengolahan nugget jantung pisang. Karena, kegiatan yang dilakukan oleh kelompok ibu-ibu arisan di perumahan Lancang Kuning hanya sebatas arisan serta pengajian yasin, sehingga, kegiatan pemberian pengetahuan serta pelatihan cara pembuatan nugget jantung pisang sebagai bahan makanan yang sehat dan bergizi menjadi suatu hal yang baru bagi kelompok ibu-ibu arisan di Perumahan Lancang Kuning.

Kegiatan pengolahan nugget jantung pisang yang diselenggarakan Tim Pengabdian 
Masyarakat Faperta Unilak sesuai dengan harapan peserta, dimana penyuluhan/pelatihan pengolahan nugget jantung pisang memberikan tambahan pengetahuan tentang manfaat pola makan yang sehat serta bergizi di kala pandemi seperti sekarang ini dan pelatihan pembuatan nugget berbahan baku jantung pisang. Personil/anggota pengabdian masyarakat yang terdiri dari Tim Dosen beserta Mahasiswa yang terlibat dalam kegiatan pengabdian masyarakat memberikan pelayanan sesuai dengan kebutuhan di dalam kegiatan penyuluhan seperti mengajarkan tentang pentingnya mengkonsumsi makanan sehat dan bergizi dengan memanfaatkan bahan-bahan yang tidak termanfaatkan disekitar perumahan yaitu jantung pisang serta cara pembuatan nugget jantung pisang beserta bahan-bahan yang diperlukan.

Peserta pengabdian terlihat sangat antusias mengikuti kegiatan pengolahan nugget jantung pisang ini, terlihat dari antusiasme peserta dengan memberikan pertanyaan-pertanyaan yang ditindaklanjuti dengan sangat baik oleh Tim Pengabdian Masyarakat dari Faperta Unilak. Antusiasme untuk keberlanjutanpun sangat dirasakan oleh Tim Pengabdian, dimana keinginan peserta untuk ikut berpartisipasi sangat tinggi jika kegiatan penyuluhan/pelatihan ini diselenggarakan kembali. Secara keseluruhan, peserta merasa puas dengan kegiatan pengabdian masyarakat yang diselenggarakan Tim Dosen Agribisnis Faperta Unilak karena kegiatan pengabdian ini sangat bermanfaat dirasakan oleh para peserta. Penelitian (Aria, Hasanuddin and Prayitno, 2016) pun menegaskan bahwa penyuluhan dan partisipasi masyarakat dapat menentukan keberhasilan program yang akan dilaksanakan dalam hal diseminasi informasi/inovasi, fasilitasi serta evaluasi.

Kegiatan pengabdian ini pada prinsipnya adalah ingin memberdayakan masyarakat khususnya ibu-ibu arisan Perumahan Lancang Kuning, Kelurahan Umbansari, Kecamatan Rumbai, Kota Pekanbaru dengan memanfaatkan waktu luangnya dengan kegiatan wirausaha. Karena, perempuan juga mempunyai andil besar dalam kegiatan penanggulangan kemiskinan melalui pemberdayaan masyarakat dan kelompok dengan melakukan kegiatan usaha produktif rumah tangga (Susanti and Susilowati, 2016).

Hal ini sejalan dengan pendapat (Mardikanto, 2009) yang menyatakan bahwa pemberdayaan dapat dilakukan dengan cara penyuluhan, sehingga berdampak pada peningkatan pengetahuan dan keterampilan masyarakat. Sehingga dapat disimpulkan bahwa pemberdayaan yang dilakukan kepada masyarakat dapat meningkatkan pengetahuan serta keterampilan masyarakat yang dibarengi dengan partisipasi/antusiasme tinggi para peserta dapat memberikan dampak kepada peserta yang diberdayakan.

\section{KESIMPULAN}

Dapat disimpulkan bahwa didalam kegiatan pengabdian ini terjadi peningkatan terhadap pengetahuan dan keterampilan peserta terhadap manfaat mengkonsumsi bahan olahan dari jantung pisang sebagai makanan tambahan menu keluarga. Hal ini berarti, bahwa pemberdayaan yang dilakukan kepada masyarakat dapat meningkatkan pengetahuan serta keterampilan masyarakat yang dibarengi dengan partisipasi/antusiasme tinggi para peserta dapat memberikan dampak kepada peserta yang diberdayakan. Untuk membantu program diversifikasi pangan pemerintah maka perlu dilakukan kegiatan dengan mengembangkan produk lain dengan bahan baku lainnya yang tidak termanfaatkan dan mensosialisasikannya 


\section{DAFTAR PUSTAKA}

Alodokter (2020) Ketahui Manfaat Jantung Pisang bagi Kesehatan, Hidup Sehat. Available at: https://www.alodokter.com/ketahui-manfaat-jantung-pisang-bagi-kesehatan (Accessed: 4 August 2021).

Aria, R. A., Hasanuddin, T. and Prayitno, R. T. (2016) 'Peranan Penyuluh Pertanian Lapangan (Ppl) Terhadap Keberhasilan Program Pengembangan Usaha Agribisnis Pedesaan (Puap) Di Kecamatan Sungkai Selatan,Kabupaten Lampung Utara', Journal JIIA, 4(4), pp. 430-436.

Hubaya, S., Karimah and Sulima (2016) 'Pengaruh Konsumsi Jantung Pisang Kepok Terhadap Peningkatan Produksi Asi Pada Ibu Menyusui Di Wilayah Kerja Puskesmas Gambesi Kota Ternate', Jurnal Kesehatan Poltekkes Ternate, 9(02), p. 39.

Kusmana, E. and Garis, R. R. (2019) 'Pemberdayaan Masyarakat Bidang Pertanian Oleh Penyuluh Pertanian Lapangan ( PPL) Wilayah Binaan Desa Buniseuri Kecamatan Cipaku Kabupaten Ciamis', Jurnal Moderat, 5(4), pp. 460-473.

Mardikanto (2009) Sistem Penyuluhan Pertanian. Surakarta: Universitas Sebelas Maret.

Novitasari, A. et al. (2013) 'Inovasi dari jantung pisang (Musa spp.)', Jurnal Kesehatan Kusuma Husada, 4(2), pp. 96-99.

Nursiah, T., Kusnadi, N. and Burhanuddin (2017) ‘Perilaku Kewirausahaan pada Usaha Mikro Kecil (UMK) Tempe di Bogor Jawa Barat', Jurnal Agribisnis Indonesia, 3(2), p. 145. doi: 10.29244/jai.2015.3.2.145-158.

Prasetyo, I. and Saddewisasi, W. (2014) 'Pemberdayaan Ibu-Ibu Rumah Tangga Untuk Berwirausaha Tembalang Kota Semarang', Jurnal Riptek, 14(1), pp. 60-64.

Sarmalina et al. (2019) 'Peningkatan Kapasitas Ibu-Ibu Arisan Sebagai Inisiator Gerakan Masyarakat Cerdas Menggunakan Obat (Gema Cermat)', Link, 15(1), p. 36. doi: 10.31983/link.v15i1.3890.

Susanti, E. and Susilowati, E. (2016) 'Pemberdayaan Ibu-Ibu PKK Melalui Pelatihan dan Pendampingan Produksi sabun dan Deterjen', SEMAR: Jurnal Ilmu Pengetahuan, Teknologi, dan Seni bagi Masyarakat, 4(2), pp. 87-96. 